IRA-International Journal of Education \&

Multidisciplinary Studies

ISSN 2455-2526; Vol.15, Issue 01 (April, 2019)

Pg. no. 32-35

Institute of Research Advances

Institute of

http://research-advances.org/index.php/IJEMS

\title{
A Study of the Differences between EFL and ESL for English Classroom Teaching in China
}

\section{Peng Si}

School of Foreign Studies, Yangtze University, Hubei, 434023 PRC China.

Type of Work: Peer Reviewed

DOl: http://dx.doi.org/10.21013/jems.v15.n1.p4

\section{How to cite this paper:}

Peng, S. (2019). A Study of the Differences between EFL and ESL for English Classroom Teaching in China. IRA International Journal of Education and Multidisciplinary Studies (ISSN 2455-2526), 15(1), 32-35.doi: http://dx.doi.org/10.21013/jems.v15.n1.p4

(C) Institute of Research Advances.

This work is licensed under a Creative Commons Attribution-Non Commercial 4.0 International License subject to a proper citation to the publication source of the work.

Disclaimer: The scholarly papers as reviewed and published by the Institute of Research Advances (IRA) are the views and opinions of their respective authors and are not the views or opinions of the IRA. The IRA disclaims of any harm or loss caused due to the published content to any party.

Institute of Research Advances is an institutional publisher member of Publishers International Linking Association Inc. (PILA-CrossRef), USA. The institute is an institutional signatory to the Budapest Open Access Initiative. Hungary advocating the open access of scientific and scholarly knowledge. The Institute is a registered content provider under Open Access Initiative Protocol for Metadata Harvesting (OAI-PMH).

The journal is indexed \& included in WorldCat Discovery Service (USA), CrossRef Metadata Search (USA), WorldCat (USA), OCLC (USA), Open J-Gate (India), EZB (Germany) Scilit (Switzerland), Airiti (China), Bielefeld Academic Search Engine (BASE) of Bielefeld University, Germany, PKP Index of Simon Fraser University, Canada. 


\begin{abstract}
Starting with the definitions of EFL and ESL, this paper compares and analyses their differences from the perspectives of the audience, teaching purposes and teaching methods, learning purposes and learning environment. Previous research found that English Classroom Teaching in China is inclined to EFL teaching, and for ESL teaching can be used for reference to improve the development of English Classroom Teaching in China.
\end{abstract}

Keywords: EFL; ESL; learning purposes; learning environment.

\title{
1. Introduction
}

From the late 1960s to the early 1970s, the theory of second language acquisition has formed an independent discipline. The theory of second language acquisition studies the psychological, cognitive processes of second language learners and language and the factors affecting second language acquisition. (Jiang Zukang, 1999 )Therefore, ESL research accounts for a large proportion of second language acquisition.

However, some researchers only know ESL research, and even equate ESL with EFL without discrimination. This paper holds that ESL and EFL are different from each other from the perspective of Definition, English Classroom Teaching and Learners. Therefore, this paper focus on distinguishing them, discovering the disadvantages of EFL teaching mode and strengthening the understanding of the characteristics of ESL teaching to help promote the development of English Classroom Teaching in China.

\section{Definition of EFL and ESL}

EFL is regarded as English as a Foreign Language, and ESL is called English as a Second Language. Before distinguishing EFL from ESL, it is important that there are differences between "foreign language" and "second language".

In his book 'Fundamental Concepts of Language Teaching', Stern(1983) referred to the differences between "foreign language" and "second language" in terms of language functions, learning purposes, language environment and learning methods. In his opinion, foreign language means the language used outside the country. Learning a foreign language is for tourism, communicating with native speakers, reading foreign journals and so on. But the Second language refers to the language that plays the same important role as mother tongue.

Shu Dingfang (1994) distinguished differences from "foreign language" and "second language" according to language environment, language input and affective factors which influence the learning process and so on. Therefore, EFL means learning English in non-English-speaking countries, while ESL means English as a second language, which has the same or even more important status as mother tongue.

Yoko Iwai(2011) defined that EFL refers to those who learn English in non-English speaking countries. (E.g. Japanese people who learn English in their country are EFL learners). and ESL refers to those who learn English in countries where English is used as a tool for communication and is formally spoken(E.g. Hispanic people who are learning English, are ESL learners.)

From the above, EFL is mainly used by non-native English learners, such as Chinese learners of English in China. While ESL refers to English learners as a second language, such as Indian and Malaysian learners. 


\section{Analysis of the differences between EFL and ESL}

\subsection{From the perspective of Teaching}

Based on the definitions of EFL and ESL, the audience of EFL are those whom English is not the first language or the official language of the country such as China, Japan and South Korea. In these countries, English isn't indispensable for daily communication. But for ESL, there are two kinds of audience. One is for people who immigrated to English-speaking countries, the other is for countries that once colonized English-speaking countries, such as Africa and Some countries in Southeast Asia. For these countries, Their English proficiency determines whether they can survive or not.

Although EFL and ESL are aimed at learning English, there are some differences in teaching purposes and methods. For ESL classroom teaching, Although the teacher is the initiator of classroom activities, students are the core of classroom activities. for example, In the oral English class of ESL mode in Australia, the teacher explains the new words and abbreviations to the students through two advertisements in the newspaper. Then students begin to read the advertisements and act as the landlord and the tenant talking with each other on the phone according to the content of the advertisements. After that, the teacher will ask two groups of students to imitate the previous conversation and then point out the problems and solve them. (Run Jianhua, Pengyan, 2008) so the part of listening, speaking, reading and writing can be trained effectively.

However, English just regards as a tool, teachers play a leading role and also the core of the class. Some teachers equated foreign language classes with history, politics, psychology classes and regarded foreign language classes as the class of acquiring knowledge. As a result, the focus of the class is mainly that the teacher gave a lecture then it got a low efficiency. (Zhao Zhongde, 2001) due to the influence of teaching syllabus, content, method, learning environment and individual differences, the four skills of listening, speaking, reading and writing can not develop simultaneously.

\subsection{From the perspective of Learners}

For ESL learners, the final purpose is to promote the development and formation of language practice, it is can be testified by Xie Lixin's (1997) study of the essence of mother tongue, second language and foreign language acquisition.ESL learners can make use of English to communicate naturally, but EFL learners hardly use English on a social occasion.

Language learning is a complex process. It is not only related to cognition, psychology, emotion and interests but also influenced by the environment. For ESL learners, they learn English in a natural condition. Just As Krashen (1985) considered, what we call "second language acquisition" is a subconscious acquisition that is similar to the process of mother tongue acquisition. When they are talking with others in English, they would think of it as social communication. Second language acquisition occurs in the target language environment, while foreign language learning occurs in the learner's native language environment when he differentiates EFL and ESL. (Wu Lihong, 1995) To a certain extent, EFL learners lack of relative environment.

\section{Enlightenment on English Classroom Teaching in China}

Since the last century, there has been a controversy about whether EFL or ESL is the basis of English classroom teaching in China. After Chen Changyi (2001) distinguished "foreign language" and "second language", they considered that English is regarded as a foreign language. Yu Shanzhi (2002) took advantage of Krashen's 
viewpoint to distinguish the two concepts of "acquisition" and "learning". He also clearly pointed out that English classroom teaching in China belongs to foreign language teaching. Based on the above viewpoints, the category of current EFL classroom teaching in China belongs to foreign language teaching. in China's English teaching.

EFL teaching has its shortcomings, learners are too passive, and learners rely on teachers to acquire information for learning. When Krashen's (1982) analyzed the concepts of "acquisition" and "learning", he pointed out that Chinese learners are learning English, not acquiring English because they can do reading and writing, but cannot communicate naturally. ESL teaching has its advantages. According to Liu Mingming's (2011) research which carried on the activities of classroom observation teacher interviews and student questionnaires in the ESL Teaching Center of the University of Wisconsin-Madison in the past semester, they made a thorough analysis of the teaching ideas and modes of ESL from three perspectives of teaching, teachers and textbooks so that they draw a conclusion that it will be helpful in the respect of Teaching Ideas, Textbook Construction and Teachers' Team Construction.

In conclusion, teachers would better turn students into the leading role and promote their initiative through multiple methods. ESL classroom teaching should be made full use on the basis of the mode of EFL teaching so as to find out a suitable way and educational mode for English classroom teaching in China.

\section{References}

[1]. Chen Changyi. The two terms "foreign language" and "second language" cannot be confused [J]. Foreign Language World, 2001: 9-14.

[2]. Hans Heinrich Stern. Fundamental concepts of language teaching-Oxford University Press [M]. 1983.

[3]. Jiang Zukang. The Study of Second Language Acquisition[M]. Beijing: Foreign Language Teaching and Research Press, 1999.

[4]. Krashen, S.D. Principles and practice in second language acquisition[M].New York: Pergamon Press. 1982.

[5]. Krashen, S.D. The input hypothesis: issues and implications[M]. Longman, 1985.

[6]. Liu Mingming. Observation and Reflection on ESL Teaching at University of Wisconsin Madison[J]. Foreign Language World, 2011:60-65.

[7]. Run Jianhua, Pengyan. English Writing Teaching Strategies Guided by ESL Integrated Teaching Model in Australia[J]. Foreign Language World, 2008(4):64-67.

[8]. Shu Dingfang. Foreign Language, Second Language, Mother tongue and another language [J]. Foreign Language Education,1994:15-19.

[9]. Wu Lihong. Language Environment and Native Language, Second Language and Foreign Language Acquisition and Learning[J]. Journal of Teachers College of Shanxi University, 1995:43-45.

[10]. Xie Lixin. Second Language Acquisition and Quasi-Acquisition in Foreign Language Teaching[J], 1997(2):49-53.

[11]. Yuko Iwai. The Effects of Metacognitive Reading Strategies: Pedagogical Implications for EFL/ESL Teachers [J]. The Reading Matrix. 2011:150-159.

[12]. Yu Shanzhi. On "Acquisition", "Acquisition" and Basic English Teaching in China[J].Foreign Language Teaching Research In Basic Education,2002: 19-23.

[13]. Zhao Zhongde. Reflections on the Crux of English Teaching in China[J]. Foreign Language and Their Teaching, 2001(10):38-39. 